\title{
Mushrooms as therapeutic agents
}

\section{Sushila Rathee, ${ }^{1}$ Dharmender Rathee, ${ }^{2}$ Deepti Rathee, ${ }^{2}$ Vikash Kumar, ${ }^{1}$ Permender Rathee ${ }^{*}, 1$}

${ }^{1}$ Prabhu Dayal Memorial College of Pharmacy, Bahadurgarh, India,

${ }^{2}$ Jan Nayak Chaudhary Devi Lal Memorial College of Pharmacy, Sirsa, India.
Revista Brasileira de Farmacognosia Brazilian Journal of Pharmacognosy 22(2): 459-474, Mar./Apr. 2012

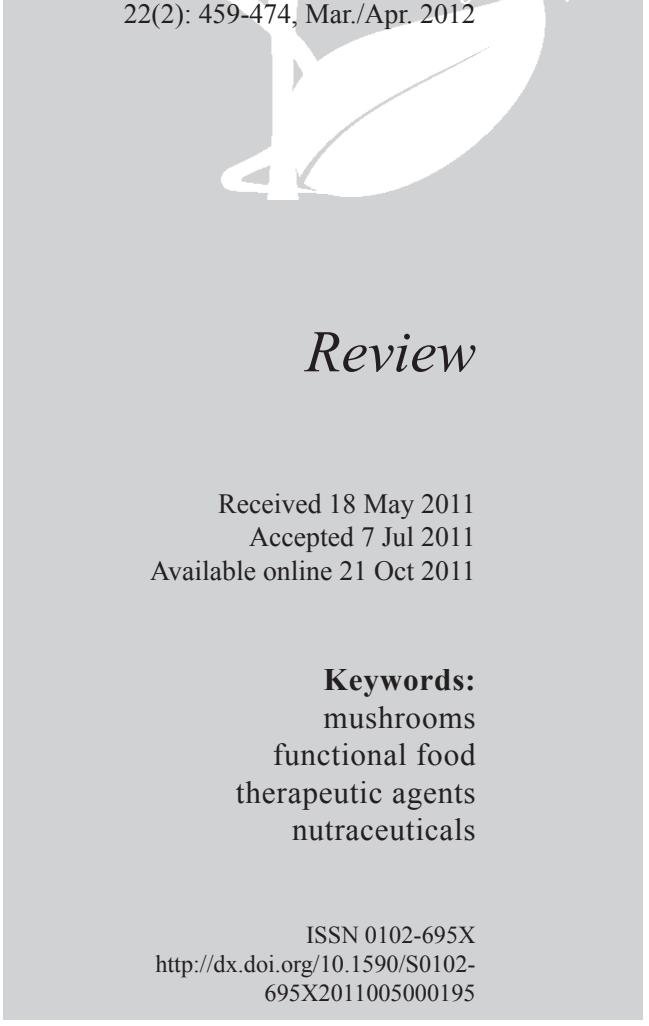

x

\begin{abstract}
Mushrooms have been known for their nutritional and culinary values and used as medicines and tonics by humans for ages. In modern terms, they can be considered as functional foods which can provide health benefits beyond the traditional nutrients. There are monographs that cover the medicinal and healing properties of some individual traditional mushrooms. There has been a recent upsurge of interest in mushrooms not only as a health food which is rich in protein but also as a source of biologically active compounds of medicinal value which include complementary medicine/dietary supplements for anticancer, antiviral, hepatoprotective, immunopotentiating and hypocholesterolemic agents. However the mechanisms of the various health benefits of mushrooms to humans still require intensive investigation, especially given the emergence of new evidence of their health benefits. In the present paper the medicinal potential of mushrooms is being discussed.
\end{abstract}

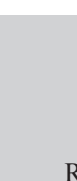

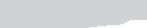

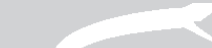


The evaluation of nutrient composition includes the determination of proteins, carbohydrates, and vitamins. The nutrient composition may be called as neutraceuticals if it provides medical or health benefits like the prevention and treatment of disease. Neutraceuticals may range from isolated nutrients and dietary supplements to genetically engineered foods, herbal products and processed products such as cereals, soups and beverages. The most common nutrients of mushrooms are as follows:

\section{Proteins and amino acids}

The crude protein content of edible mushrooms is usually high, but varies greatly and is affected by factors such as species and stage of development (Longvah \& Deosthale, 1998). The crude protein content of some common edible mushrooms varies from approx. 10.0-40\% w/w (Barros et al., 2008; Longvah \& Deosthale, 1998; Diez \& Alvarez, 2001). The essential amino acid content ( $\mathrm{g} / 100 \mathrm{~g}$ protein) of mushrooms ranges from approx. 34 to $47 \%$. The essential amino acid profiles of mushrooms reveal that the proteins are deficient in sulfur-containing amino acids, including methionine and cysteine. However, these edible mushrooms are comparatively rich in threonine and valine. It has been reported that lysine, leucine, isoleucine, and tryptophan are the limiting amino acids in some edible mushroom proteins (Barros et al., 2008; Diez \& Alvarez, 2001; Cheung, 1997). The free amino acid level in mushrooms is low, ranging from 7.14 to $12.3 \mathrm{mg} / \mathrm{g}$ in dry edible mushrooms and contribute to the main flavor properties of mushrooms (Sugahara et al., 1975; Maga, 1981).

\section{Vitamins}

Cultivated mushrooms are a good source of several vitamins, such as riboflavin, niacin, and folates, with concentrations that vary within the range of 1.85.1, 31-65, and 0.30-0.64 mg/100 g dry weight (DW), respectively, depending on the species. The vitamin B2 content in mushrooms is higher than that generally found in vegetables, and in some varieties even have a level as that found in egg and cheese (Mattila et al., 2001). Mushrooms contain moderately high amounts of folates at concentrations that are of the same magnitude as is generally found in vegetables. Furthermore, the bioavailability of folates is as good as that for folic acids (Clifford et al., 1991) with a content of 300-1412 $\mu \mathrm{g} / 100 \mathrm{~g}$. In addition to riboflavin, niacin and folates, cultivated mushrooms also contain small amounts of vitamin $\mathrm{C}$ and vitamin $\mathrm{B} 1$ and traces of vitamins B12 and D2 (Mattila et al., 2001).

\section{Carbohydrates}

The carbohydrate content of edible mushrooms varies with species and ranges from 35 to $70 \% \mathrm{DW}$ (Mau et al., 2001; Mau et al., 2001). Edible mushrooms are believed to contain a high level of oligosaccharides and only a low level of total soluble sugars (Bano \& Rajarathnam, 1988).

\section{Fatty acids}

The fatty acid level in mushrooms is generally low, around $2-8 \%$ of distilled water. The level of polyunsaturated fatty acids as compared to saturated fatty acids is quite high, constituting more than $75 \%$ of total fatty acids, of which oleic and lenoleic acids are the most significant (Ribeiroa et al., 2009), while palmitic acid is the main saturated fatty acid.

\section{Therapeutic potential of mushrooms}

The major attribute of mushrooms is their medicinal properties which have been the main focus of researchers around the world. The momentous pharmacological and physiological properties of mushrooms are immune enhancement, maintenance of homeostasis and regulation of biorhythm, cure \& prevention of various diseases and improvement from life threatening diseases such as cancer, stroke and heart diseases. The various activities of mushrooms have been studied which includes hypotensive and renal effects (Ribeiroa et al., 2009), immuno-modulatory and antitumor activities of polysaccharide-protein complex (PSPC) from mycelial cultures (Yip et al., 1987) immuno-modulatory and antitumor activities of lectins from edible mushrooms (Wang et al., 1995) and various other medicinal effects of most commonly studied $G$.

lucidum (Wang et al., 1996; Chang et al., 1993).

The present paper gives an overview about the present knowledge about the pharmacological potential of mushrooms. A brief description of the chemical constituents and potential effects of mushrooms have been given in Table 1 .

\section{Health benefits of mushrooms}

Due to the greater attention being paid to the potential health benefits of mushrooms to humans has resulted in many scientific publications, to the extent that there is now a database of scientific evidence about the specific health effects of mushrooms and their bioactive molecules. These include: 
Table 1. The reported biological activity of mushrooms \& active constituents.

\begin{tabular}{|c|c|c|}
\hline Biological name of mushroom & Active principle/constituents/extracts & Activity reported \\
\hline Auricularia auricula-judae (Bull.) J.Schrot. & Methanolic extracts, dietary fiber & $\begin{array}{l}\text { Antioxidant (Yip et al., 1987), } \\
\text { Hypocholesterolemic (Cheung, 1996) }\end{array}$ \\
\hline Agrocybe cylindracea (DC.) Maire & $\beta$-Glucans & $\begin{array}{l}\text { Antioxidant (Chang, 1993), Hypoglycemic (Kiho } \\
\text { et al., 2000) }\end{array}$ \\
\hline Agrocybe aegerita & $\begin{array}{l}\text { Water and methanolic extracts, total } \\
\text { phenolic content }\end{array}$ & $\begin{array}{l}\text { Antioxidant (Mau et al., 2001), } \\
\text { Hypocholesterolemic (Ng, 2005) }\end{array}$ \\
\hline Agaricus bisporus (J.E.Lange) Imbach & Fibers, lectins & $\begin{array}{l}\text { Hypocholesterolemic (Fukushima et al., } 2000 \text { \& } \\
\text { 2001), Hypoglycemic (Ahmad et al., 1984) }\end{array}$ \\
\hline Agaricus campestris L. & Lectins & Hypoglycemic (Ahmad et al., 1984) \\
\hline Astralagalus campertris & Non-lectin-type component & Hypoglycemic (Gray \& Flatt, 1998) \\
\hline Boletus edulis Bull. & Extracts of fruiting bodies & Antitumor (Lucas et al., 1957) \\
\hline Calvatia gigantean (Batsch ex Pers.) Lloyd & Calvacin & Antitumor (Lucas et al., 1958) \\
\hline Collybia maculate (Alb. \& Schwein.) P. Kumm. & Purine derivatives & Antiviral activity (Leonhardt et al., 1987) \\
\hline Eurotium chevalieri Mangin & Flavoglaucin & Antioxidant (Mau et al., 2002) \\
\hline Flammulina velutipes (Curtis) Singer & Fibers, ethanolic extracts & $\begin{array}{l}\text { Antioxidant (Wang et al., } 1995 \text { \& 1996), } \\
\text { Hypocholesterolemic } \\
\text { (Fukushima et al., } 2000 \text { \& 2001), Antiallergic } \\
\text { (Sano et al., 2002) }\end{array}$ \\
\hline Grifola frondosa (Dicks.) Gray & MD-fraction, ergosterol (1) & $\begin{array}{l}\text { Antioxidant (Wang et al., } 1995 \text { \& 1996), } \\
\text { hypotensive, Hypoglycemic (Horio et al., 2001), } \\
\text { Immunotherapy (Hazama et al., 1995), Anti- } \\
\text { inflammatory activity (Zhang et al., 2002) }\end{array}$ \\
\hline Ganoderma lucidum (Curtis) P. Karst & $\begin{array}{l}\text { Ganoderan A and B, glucans, Triterpenes } \\
\text { (ganoderiol F (2), ganodermanontriol } \\
\text { (3), ganoderic acids (4) A, B, D, F, G, H, } \\
\text { Z), ganosporeric acid A, ganopoly, the } \\
\text { polysaccharide-containing preparation }\end{array}$ & $\begin{array}{l}\text { Hypoglycemic (Hikino et al., 1985), antioxidant } \\
\text { and antitumor (Thekkuttuparambil et al., 2007), } \\
\text { antiviral (HIV-1) (El-Mekkawy et al., 1998), } \\
\text { Antiallergic (Kohda et al., 1985; Tasaka et al., } \\
\text { 1988), Anti-inflammatory (Koyama et al., 1997), } \\
\text { antihepatotoxic (Hirotani et al., 1986; Chen \& } \\
\text { Yu, 1993, inhibit the biosynthesis of cholesterol } \\
\text { (Komoda et al., 1989), antioxidative and free } \\
\text { radical scavenging effects (Lin, 2004) }\end{array}$ \\
\hline Ganoderma pfeifferi Bres. & $\begin{array}{l}\text { Sesquiterpenoid hydroquinones, } \\
\text { ganodermadiol (5), lucidadiol (6) and } \\
\text { applanoxidic acid } G(7)\end{array}$ & $\begin{array}{l}\text { Antimicrobial (Mothana et al., 2000), Antiviral } \\
\text { (Mothana et al., 2003) }\end{array}$ \\
\hline Ganoderma annulare (Pers.) Bres. & Applanoxidic acid A (8) & Antifungal (Smania et al., 2003) \\
\hline Ganoderma applanatum (Pers.) Pat. & $\begin{array}{l}\text { Steroids like } 5 \alpha \text {-ergosta- } 7,22 \text {-dien- } 3 \beta \text {-ol } \\
\text { or } 5,8 \text {-epidioxy- } 5 \alpha, 8 \alpha \text {-ergosta- } 6,22 \text { - } \\
\text { dien-3 } 3 \text {-ol }\end{array}$ & $\begin{array}{l}\text { Antimicrobial (Smania et al., 1999), Analgesic } \\
\text { (Melzig et al., 1996) }\end{array}$ \\
\hline Hericium erinaceus (Bull.) Pers. & $\begin{array}{l}\text { Phenol-analogous compounds } \\
\text { (hericenons C, D, E, F, G, H) }\end{array}$ & $\begin{array}{l}\text { Antioxidant (Wang et al., } 1995 \text { \& 1996), } \\
\text { ameliorative effect in Alzheimer's dementia } \\
\text { (Mizuno, 1999) }\end{array}$ \\
\hline Hypsizigus marmoreus & Ethanolic extracts & $\begin{array}{l}\text { Antioxidant (Chang, 2004), Antiallergic (Sano et } \\
\text { al., 2002) }\end{array}$ \\
\hline Hericium coralloides (Scop.) Pers. & Erinacin E (9) & Antinociceptive (Saito et al., 1998) \\
\hline Inonotus obliquus Linn. & Fruiting bodies & $\begin{array}{l}\text { Used as a folk medicine for cancer and stomach } \\
\text { diseases (Molitoris, 1994) }\end{array}$ \\
\hline Inonotus hispidus (Bull.) P. Karst. & $\begin{array}{l}\text { Hispolon (10) and hispidin (11), } \\
\text { phenolic compounds }\end{array}$ & $\begin{array}{l}\text { Antiallergic (Ali et al., 1996), Antiviral activity } \\
\text { (Awadh et al., 2003) }\end{array}$ \\
\hline $\begin{array}{l}\text { Kuehneromyces mutabilis (Schaeff.) Singer \& } \\
\text { A. H. Sm. }\end{array}$ & Mycelial extracts & Antiviral activity (Mentel et al., 1994) \\
\hline Lentinula edodes (Berk.) Pegler & $\begin{array}{l}\text { Methanolic and water extracts, } \\
\text { eritadenine (12), lentinan, oxalic acid, } \\
\text { ethanolic mycelial extracts }\end{array}$ & $\begin{array}{l}\text { Antioxidant (Wang et al., } 1995 \text { \& 1996), } \\
\text { Hypocholesterolemic (Lee et al., 2007; Cheung, } \\
\text { 2001), Immunotherapy (Hazama et al., 1995), } \\
\text { Antimicrobial (Bender et al., 2003), antiprotozoal } \\
\text { (Badalyan, 2004) }\end{array}$ \\
\hline
\end{tabular}


Laricifomes officinalis (Vill.) Kotl. \& Pouzar

Laetiporus sulphureus (Bull.) Murrill

Lenzites betulina (L.) Fr.

Pleurotus ostreatus (Jacq. ex Fr.) P. Kumm.

Pleurotus tuberregium (Rumph. ex Fr.) Singer

Pleurotus cornucopiae Singer

Pleurotus pulmonaris (Fr.) Quel.

Pholiota nameko (T. Ito) S. Ito \& S. Imai

Pleurotus eryngii (DC.) Quel.

Phellinus linteus

Polyporus umbellatus

Schizophyllum commune Fries

Scutiger ovinus

Scutiger confluens

Tremella fuciformis Berk.

Trametes versicolor (L.:Fr.) Quel.

Tricholoma populinum

Volvariella volvacea (Bulliard ex Fries) Singer

Wolfiporia cocos (F.A. Wolf)
Dehydrotrametenolic acid (13)

Dehydrotrametenolic acid

Betulinan A (14)

Water and $30 \%$ ethanolic extract

Crude methanolic and water extracts

Dietary fiber

Methanolic extract

Ethanolic extracts

Ethanolic extracts

Ethanolic extracts and a proteoglycan

$5 \alpha, 8 \alpha$-epidioxy-ergosta-6,22-dien-3-ol

Schizophyllan

Scutigeral (15)

Albaconol (16)

Acidic polysaccharide from the fruiting bodies

Coriolan, a $\beta$-glucan-protein complex

Whole mushrooms

Methanolic and water extracts, exopolysaccharides

Dehydrotrametenolic acid
Hypoglycemic (Sato et al., 2002)

Hypoglycemic (Sato et al., 2002)

Inhibition of lipid peroxidation (Lee et al., 1996)

Antioxidant (Wang et al., 1995 \& 1996),

Hypocholesterolemic (Bobek et al., 1991 \& 1993)

Antioxidant

Hypocholesterolemic (Ryong et al., 1989)

Antioxidant and antitumor (Thekkuttuparambil et al., 2007), Anti-inflammatory (Jose et al., 2002)

Antiallergic (Sano et al., 2002)

Antiallergic (Sano et al., 2002)

Anti-inflammatory activity (Kim et al., 2003 \& 2004)

Potentiators of ADP-induced platelet aggregation (Lu et al., 1985)

Immunotherapy (Hazama et al., 1995)

Pain killer (Szallasi et al., 1999)

Antagonist at the VR1 receptor (Liu, 2002)

Hypoglycemic (Kiho et al., 1994)

Hypoglycemic (Hikino et al., 1985),

Immunotherapy (Hazama et al., 1995)

Antiallergic (Kreisel et al., 1990)

Antioxidant, Hypocholesterolemic (Cheung, 1996)

Hypoglycemic (Sato et al., 2002)<smiles>CC(C)[C@H](C)/C=C/[C@H](C)[C@H]1CC[C@H]2C3=CCC4C[C@@H](O)CC[C@]4(C)C3CC[C@]21C</smiles><smiles>CC(CC[C@@H](O)[C@@](C)(O)CO)[C@H]1CC[C@]2(C)C3=CC[C@H]4C(C)(C)C(=O)CC[C@]4(C)C3=CC[C@]12C</smiles>

3<smiles>CC(CCC=C(CO)CO)C1CC[C@]2(C)C3=CC[C@H]4[C@@H](C)[C@@H](O)CC[C@]4(C)C3=CC[C@]12C</smiles>

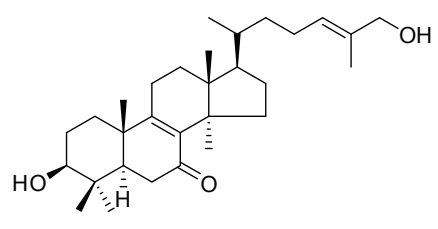<smiles>CC(CCC=C(CO)CO)[C@H]1CC[C@]2(C)C3=CC[C@H]4C(C)(C)[C@@H](O)CC[C@]4(C)C3=CC[C@]12C</smiles>

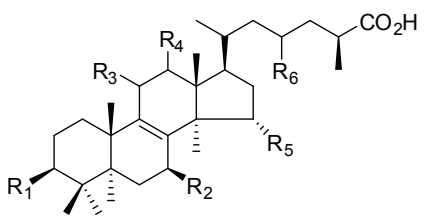

4a Ganoderic acid $A: R_{1}=R_{3}=R_{6}=O ; R_{2}=R_{5}=O H ; R_{4}=H$ 4b Ganoderic acid $B: R_{1}=R_{3}=R_{6}=R_{5}=O ; R_{2}=O H ; R_{4}=H$ 4c Ganoderic acid $D$ : $R_{1}=R_{3}=R_{6}=R_{5}=O ; R_{2}=R_{4}=O H$ 4d Ganoderic acid $F: R_{1}=R_{2}=R_{3}=R_{6}=R_{5}=O ; R_{4}=O H$ 4e Ganoderic acid G: $\mathrm{R}_{1}=\mathrm{R}_{2}=\mathrm{R}_{4}=\mathrm{OH} ; \mathrm{R}_{3}=\mathrm{R}_{5}=\mathrm{R}_{6}=\mathrm{O}$ 4f Ganoderic acid $\mathrm{H}$ : $\mathrm{R}_{1}=\mathrm{OH} ; \mathrm{R}_{2}=\mathrm{R}_{5}=\mathrm{R}_{3}=\mathrm{R}_{6}=\mathrm{O} ; \mathrm{R}_{4}=\mathrm{OAc}$

$4 \mathrm{~g}$ Ganoderic acid Z: $\mathrm{R}_{1}=\mathrm{OH} ; \mathrm{R}_{2}=\mathrm{R}_{3}=\mathrm{R}_{4}=\mathrm{R}_{5}=\mathrm{R}_{6}=\mathrm{H}$

4h Ganosporeric acid $A: R_{1}=R_{2}=R_{3}=R_{4}=R_{5}=R_{6}=H$

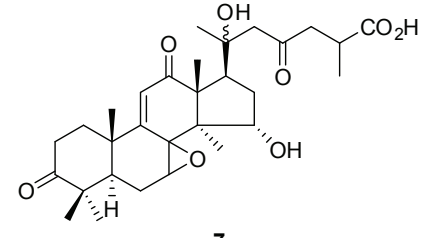




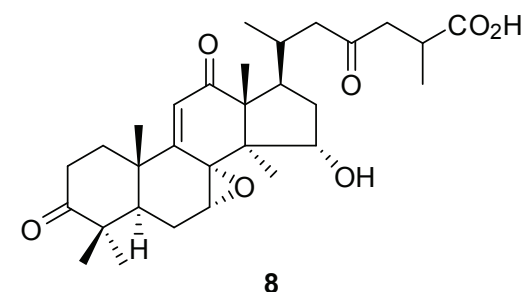

8<smiles>CC(=O)/C=C(O)/C=C/c1ccc(O)c(O)c1</smiles>

10

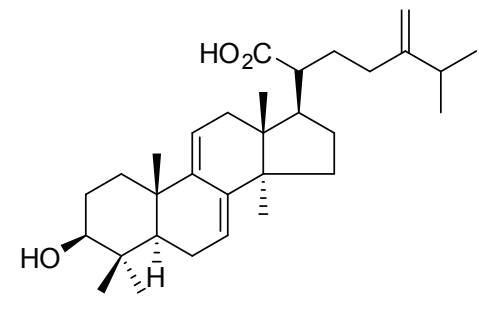

13<smiles>CC(C)=CCC/C(C)=C/CC/C(C)=C/Cc1c(C)c(C=O)c(O)c(O)c1O</smiles>

15

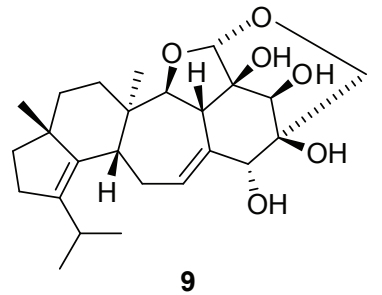

9

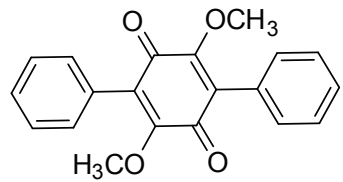

14<smiles>Cc1cc(O)c(C[C@@H]2[C@@](C)(O)CC[C@]3(C)[C@H](C)CCC[C@@]23C)c(O)c1</smiles>

16

2001; Yang et al., 2002).

Similar antioxidant properties have also been reported for other edible mushrooms, including Agrocybe cylindracea (Mau et al., 2002) and H. marmoreus, both of which belong to the Tricholomataceae family (Tsai et al., 2006). Potent antioxidant activity was also found in crude methanolic and aqueous extracts of the common Chinese edible mushrooms L. edodes (shiitake mushroom), Pleurotus tuber-regium and $V$. volvacea (straw mushroom) and a lesser known edible mushroom, A. aegerita, belonging to the family Bolbitiaceae, was evaluated by the $\beta$-carotene bleaching method, DPPH radical scavenging activity and erythrocyte hemolysis assay (Lee et al., 2007). Fractionation of the crude methanolic and aqueous extracts of $L$. edodes, $P$. tuber-regium and $V$. volvacea further indicated that the dichloromethane and ethyl acetate fractions of these mushrooms have the strongest antioxidant activity and have the lowest median effective 
concentration (EC50) values (Cheung, 2001).

The antioxidant activity and antioxidant compounds in seven wild edible mushrooms (Lo \& Cheung, 2005) were determined, including phenolics, $\beta$-tocopherol and $\beta$-carotene in methanolic extracts, and their in vitro antioxidant systems, including their reducing power, free-radical scavenging, superoxide anion radical scavenging, total antioxidant activity, and metal-chelating activities. Phenolics with antioxidant ability have also been found in other mushroom species. Flavoglaucin, which is a phenolic compound isolated from the mycelial mat of Eurotium chevalieri, is an excellent antioxidant in vegetable oil at a concentration of $0.05 \%$ (Elmastas et al., 2007). In most of these studies a positive correlation was found between the total phenolic content in the mushroom extracts and their antioxidative properties, which confirms that edible mushrooms have a potential as natural antioxidants due to the ability of their phenolics to inhibit lipid oxidation.

\section{Mushrooms as hypocholesterolemic agents}

Cardiovascular disease is associated with atherosclerosis, LDL oxidation, and hypercholesterolemia, and thus the regulation of the cholesterol level is important for the prevention and treatment of this disease. Edible mushrooms are an ideal food for the dietetic prevention of atherosclerosis due to their high fiber and low fat content. Indeed, the inclusion of edible mushrooms in a natural hypocholesterolemic and antisclerotic diet is often prescribed in Oriental medicine (Ishikawa et al., 1984). Initial research on the cholesterol-lowering effects of mushrooms was conducted in Japan in the 1960s, and it was demonstrated that when rats were fed with a highfat and high-cholesterol diet supplemented with 5\% water of the fruiting bodies of $L$. edodes for ten weeks, the plasma cholesterol levels of the animals decreased significantly (Sun et al., 1984). The adenosine derivative lentinacin or lentysine (currently known as eritadenine [2(R), 3(R)-dihydroxy-4-(9-adenyl)-butyric acid] (12) was subsequently isolated and identified to be one of the active hypocholesterolemic components in the shiitake mushroom (Kaneda \& Tokuda, 1966).

Eritadenine has also been found to reduce the serum cholesterol level in mice by the acceleration of the excretion of ingested cholesterol and its metabolic decomposition (Tokita et al., 1972). Eritadenine affects the metabolism not only of cholesterol but also of phospholipids and fatty acids in rats (Suzuki \& Ohshima, 1976; Sugiyama et al., 1995). The dietary supplementation of eritadenine may therefore decrease phosphatidylcholine biosynthesis by altering the phosphatidylethanolamine concentration (Shimada et al., 2003). Similar to soybean protein, eritadenine lowers cholesterol by decreasing the ratio of phosphatidylcholine (PC) to phosphatidylethanolamine (PE) in liver microsomes and altering the composition of PC (Sun et al., 1984). Eritadenine can also suppress the metabolism of lipids (linoleic acid) by suppressing 1 , 6-desaturase activity. Several other studies on Lentinula extracts have shown them to cause a significant decrease in serum cholesterol in young women and people older than 60 years of age in Japan (Tokita et al., 1972).

Recently, it has been reported that eritadenine may elicit its effect by the suppression of the hyperhomocysteinic effect of guanidinoacetic acid, which leads to the decreased production of homocysteine and increased cystathionine formation (Suzuki \& Ohshima, 1976). In addition to eritadenine, nucleic acid compounds extracted from $L$. edodes were found to be inhibitors of platelet agglutination (Sugiyama et al., 1995). Lovastatin and its analogues are powerful inhibitors of 3-hydroxy-3-methyl-glutaryl-CoA (HMG-CoA) reductase and as such are well-known cholesterol-lowering agents (Shimada et al., 2003). It has also been found that the addition of 2 and $4 \%$ of $P$. ostreatus to a hyperlipidemic diet can prevent the accumulation of cholesterol and triacylglyceride in both the sera and livers of rats with exogenous, endogenous, or genetically induced hyperlipidemia (Bobek et al., 1991; Bobek et al., 1993). A reduction of the serum cholesterol level of up to $80 \%$ was also observed from the feeding of the whole mushroom, water and $30 \%$ ethanol extract of $P$. ostreatus to rats. In another study, dietary fiber extracted from $P$. cornucopiae had a marked antiatherosclerotic effect in vitro, and patients with coronary disease showed a decreased atherogenic activity (20-40\%) in their sera after the consumption of this mushroom, which confirms that it has a natural cholesterol-lowering agent that is responsible for this hypocholesterolemic effect (Ryong et al., 1989). Addition of 1-5\% of oyster mushroom to a hyperlipidemic diet efficiently prevents the accumulation of LDL cholesterol and triacylglyceride in both the blood and liver of rats with hyperlipidemia (Bobek et al., 1998) and also reduces cholesterol biosynthesis by suppressing the activity of hepatic HMG-CoA reductase (Bobek et al., 1995) and accelerated cholesterol catabolism by up-regulating hepatic cholesterol 7 $\beta$-hydroxylase (Bobek et al., 1994). It has been suggested that the fruiting bodies of oyster mushrooms could be recommended for consumption as a natural cholesterol-lowering agent in the human diet (Cimerman, 1999).

In addition to lovastatin and eritadenine, dietary fibers (nonstarch polysaccharides, mainly $\beta$-glucans) has also been suggested to be an important hypocholesterolemic component in mushrooms, and dietary fiber isolated from 
Auricularia auricula-judae (Jew's ear) and Tremella fuciformis (white jelly-leaf) can significantly decrease the serum total cholesterol (TC) and LDL cholesterol levels (Cheung, 1996). Furthermore, exopolysaccharides produced by the submerged fermentation of the mycelium of $V$. volvacea can reduce the levels of serum TC, LDL cholesterol, and liver TC in alimentarially induced hypercholesterolemic rats (Cheung 1996). Fibers from $F$. velutipes (enokitake mushroom) and A. bisporus (button mushroom) can dramatically enhance the hepatic LDL receptor messenger RNA (mRNA), causing the diminution of the serum TC (Fukushima et al., 2000; Fukushima et al., 2001).

Mushroom like A. auricula-judae, display anticoagulation, antiaggregatory activity in the blood platelets of mice and rats, thus serving to lower their total cholesterol, total triacylglyceride, and lipid levels (Chen, 1989; Sheng \& Chen, 1990). G. frondosa, reduced blood pressure in rats without changing the plasma high-density lipoprotein (HDL) level or serum cholesterol level (Mizuno, 1995). Various studies have shown that Lentinula mushrooms can lower both the blood pressure and the free cholesterol level in plasma and can accelerate the accumulation of lipids in the liver by removing them from circulation (Kabir \& Kimura, 1989). It has also been reported that dried A. aegerita can significantly reduce the serum TC, triacylglyceride, atherogenic index, hepatic TC, and total triacylglyceride levels in rats fed a semisynthetic high-cholesterol diet compared with the control group (Yeung \& Cheung, 2002). The hypocholesterolemic effect of $A$. aegerita has been suggested to be linked with its antioxidant activity (Ng, 2005).

\section{Mushrooms as hypoglycemic agents}

An extensive search for traditional plant treatments for diabetes has concluded that recognized edible mushrooms are an ideal food for the dietetic prevention of hyperglycemia because of their high dietary fiber and protein and low fat content (Alarcon-Aguilara et al., 1998). Many studies have been conducted on the hypoglycemic activity of whole mushrooms and their fruiting bodies (Horio et al., 2001) and on mushroom bioactive components, including polysaccharides (Kiho et al., 1994; Kiho et al., 1994; Kiho et al., 2002; Kiho et al., 2000; Kiho et al., 1995) and lectins (Ewart et al., 1975) isolated from the fruiting bodies. Moreover, endo and exopolymers produced in submerged mycelial cultures have also been found to have a hypoglycemic effect (Kim et al., 2001; Kim et al., 1997). The most common animal models used for the study of the hypoglycemic effects of mushrooms are rats and mice with insulin-dependent diabetes mellitus (IDDM) induced by streptozotocin (STZ) and genetically diabetic mice with non-insulin- dependent diabetes mellitus (NIDDM) (Beattie et al., 1980; Swanston-Flatt et al., 1989). The administration of $G$. frondosa to IDDM STZ diabetic albino Wistar rats at $20 \%$ dry weight in a semipurified diet for 100 days resulted in an increase in insulin excretion and a decrease in the blood glucose level in the animals. It has also been demonstrated that $G$. frondosa has an antidiabetic effect in NIDDM KK-Ay mice, which is produced by reducing the blood glucose level (Kurushima et al., 2000; Kubo et al., 1994; Kubo \& Nanba, 1997). The $\beta$-glucans isolated from A. cylindracea showed remarkable hypoglycemic activity in both normal and STZ-induced diabetic mice when administered intraperitoneally. The antidiabetic activity of Tremella aurantia may also be mediated by an increase in the activities of glucokinase, hexokinase, and glucose6-phosphate dehydrogenase and a decrease in the activity of glucose-6-phosphatase in normal and IDDM diabetic mouse livers after intraperitoneal administration (Kiho et al., 2000). Another acidic polysaccharide from the fruiting bodies of T. fuciformis was found to be effective in STZinduced diabetic mice when administered orally (Kiho et al., 1994).

Lectins isolated from mushrooms (Agaricus campestris and $A$. bisporus) have been shown to enhance insulin release in isolated Langerhans rat islets (Ahmad et al., 1984). The presence of a nonlectin-type component in A. campertris that displays insulin-releasing and insulin-like activity has also been reported (Gray\& Flatt, 1998). Guanidine, which is a known hypoglycemic substance related to the biguanide class of oral antidiabetic drugs, has been found in edible mushrooms (Windholz, 1983), but the detailed principles of these active components in mushrooms remain to be elucidated.

Ganoderan A and B, glucans from G. lucidum fruiting bodies (Hikino, 1985), coriolan, a $\beta$-glucanprotein complex obtained from submerged grown $T$. versicolor biomass exhibited hypoglycemic effects in several test systems and ameliorated the symptoms of diabetes. Seventy-one patients with confirmed type II diabetes were treated with polysaccharide fractions from G. lucidum (Ganopoly, $1800 \mathrm{mg}$ three times daily for twelve weeks). The mean post-prandial glucose values had decreased to $11.8 \mathrm{mmol}$ in the Ganopoly group (Gao et al., 2004). Preparations from the traditional Chinese drug Cordyceps (consisting of fungi parasitic in insects) and from fermented mycelia meliorate diabetes in a diabetic animal model using streptozotocin-induced rats after p.o. application (Hsu \& Lo, 2002).

Dehydrotrametenolic acid (13), found in several polypores including Wolfiporia cocos, Laricifomes officinalis and Laetiporus sulphureus Murrill, acts as an insulin sensitizer in glucose tolerance tests and reduces hyperglycemia in mice with noninsulin-dependent diabetes 
(Sato et al., 2002).

\section{Mushrooms as antitumor agents}

The mushroom Cordyceps militaris has been used for a long time in eastern Asia as a nutraceutical and in traditional Chinese medicine as a treatment for cancer patients. CMP exerted strong antifungal effect against the growth of the fungus Fusarium oxysporum, and exhibited cytotoxicity against human breast and bladder cancer cells. New discoveries in molecular oncology along with rapid expansion of our knowledge concerning the processes that govern differentiation, apoptosis, immune surveillance, angiogenesis, metastasis, cell cycle, and signal transduction control have unveiled an abundance of specific molecular targets for cancer therapy, including a variety of smallmolecule compounds that inhibit or stimulate these molecular targets.

In one study, it was found that Ganoderma lucidum, Phellinus rimosus, Pleurotus florida and Pleurotus pulmonaris possessed profound antioxidant and antitumoractivities (Thekkuttuparambiletal.,2007). The antitumor activity of the higher Basidiomycetes extracts of fruiting bodies of Boletus edulis and other Homobasidiomycetes were tested against the Sarcoma 180 line in mice (Lucas et al., 1957) and were found to have significant activity. In the 1960 s, calvacin was the most commonly cited natural product isolated from the medicinal mushroom and was broadly used in many laboratories as an antitumor agent. Calvacin was isolated from the giant puffball (Calvatia gigantean) (Lucas et al., 1958) and it was found effective against many experimental tumors, including Sarcoma 180 mammary adenocarcinoma 755, leukemia L-1210, and HeLa cell lines. There are approximately 650 species of higher Basidiomycetes that have been found to possess antitumor activity (Wasser, 2002; Mizuno , 1995).

In Eastern Europe, the fruiting bodies of $I$. obliquus have been used as a folk medicine for cancer and stomach diseases since the $16^{\text {th }}$ or $17^{\text {th }}$ century (Molitoris, 1994). Antitumor effects of several extracts and isolated compounds from mushrooms have been demonstrated in tumor cell systems and in animal assays (Kahlos et al., 1987; Burczyk et al., 1996). Searching for new antitumor and other medicinal substances from mushrooms and studying the medicinal value of these mushrooms has become a matter of great significance.

\section{Mushrooms as immunomodulators}

So called 'immunomodulators' (biological response modifier, immunopotentiators and immunostimulants) are the most important medicinal mushroom drugs used especially in Japan, China,
Korea and other East Asian countries today. Some polysaccharides or polysaccharide-protein complexes from mushrooms are able to stimulate the non-specific immune system and to exert antitumor activity through the stimulation of the host's defence mechanism (Chihara et al., 1969; Mizuno, 1999; Wasser \& Weis, 1999; Reshetnikov et al., 2001). These drugs activate effector cells like macrophages, T lymphocytes and NK cells to secrete cytokines like TNF-a, IFN-g, IL-1b, etc., which are antiproliferative and induce apoptosis and differentiation in tumor cells (Wasser \& Weis, 1999; Reshetnikov et al., 2001). There is evidence that $\beta$-d-glucans induce a biological response by binding to membrane complement receptor type 3 (CR3, alphaMb2 integrin or CD11b/CD18) on immune effector cells. The ligand-receptor complex can be internalized. The intercellular events that occur after glucan-receptor binding have not been fully determined till now (Zhou $\&$ Gao, 2002). In one experimental approach it was shown that schizophyllan produced by $S$. commune was able to bind the mRNA poly (A) tail (Karinaga et al., 2004).

Lentinan from L. edodes, schizophyllan from S. commune, MD-fraction from $G$. frondosa and compounds from $T$. versicolor (PSK and PSP) are in clinical use (i.e. 0.5-1.0 $\mathrm{mg}$ lentinan per day, intravenous), especially in Japan and China, for the adjuvant tumor therapy (immunotherapy) in addition to the major cancer therapies like surgical operation, radiotherapy and chemotherapy. Application of lentinan (parenteral) in addition to chemotherapy led to prolongation of survival time, restoration of immunological parameters and improvement of life quality in patients with stomach cancer, colon cancer and other carcinomas in comparison to patients who had chemotherapy alone (Hazama et al., 1995). In a randomized multicentric study with 89 stomach cancer patients, the median survival time in the immunochemotherapy group (chemotherapy and lentinan $2 \mathrm{mg}$ per week, intravenous) was 189 days and in the control group (only chemotherapy) 109 days (Ochiai et al., 1992). In another study of patients with advanced colorectal cancer, the median survival time was 200 days in the lentinantreated group ( $2 \mathrm{mg}$ per week, 23 patients) and 94 days in the control group (Taguchi et al., 1982). In a controlled randomized study, 130 patients were treated with schizophyllan (intramuscular $40 \mathrm{mg}$ per week, totally $1134 \mathrm{mg}$ ) after surgical removal of the whole tumor tissue additionally to application of mitomycin and futraful. The schizophyllan treatment started at day 14 after operation. The median survival time after five years was $72.2 \%$ in the schizophyllan group and $61.9 \%$ in the control group (134 patients, chemotherapy only). Schizophyllan had no effect 
on the survival time when the tumor tissue could not be removed totally (Fujimoto et al., 1991). The immunostimulating effect of lentinan was also investigated in patients with AIDS. In a phase II study, $107 \mathrm{HIV}$ positive patients were treated with didanosin (400 mg per day, p.o. 6 weeks). After that time, 88 patients got additionally $2 \mathrm{mg}$ lentinan per week intravenous for 24-80 weeks, the patients of the control group got only didanosin. The combined treatment resulted in a significant increase of the number of CD4 $\beta$ cells after 38 weeks in comparison to control group (Gordon et al., 1995).

In a non-random case series, a combination of MD-fraction and whole powder of G. frondosa was investigated to determine its effectiveness for 22 to 57 years old cancer patients in stages II-IV. Cancer regression or significant symptom improvement was observed in $58.3 \%$ of liver cancer patients, $68.8 \%$ of breast cancer patients and $62.5 \%$ of lung cancer patients. The trial found a $<10-20 \%$ improvement for leukemia, stomach cancer and brain cancer patients (Kodama et al., 2002). The MD-fraction has been approved by the Food and Drug Administration (FDA) for an Investigational New Drug application to conduct a phase II pilot study on patients with advanced breast and prostate cancer (Konno et al., 2002).

\section{Mushrooms as antimicrobial agents}

Mushrooms need antibacterial and antifungal compounds to survive in their natural environment. Hence, they are rich sources of natural antibiotics. Many of the externalized secondary metabolites (extracellular secretions by the mycelium) are known to combat bacteria (Benedict \& Brady, 1972; Kupra et al., 1979; Lindequist et al., 1990) and viruses (Eo et al., 1999). Several compounds extracted from mushroom revealed antifungal and antibacterial activity, namely against Staphylococcus aureus, Bacillus subtilis and Escherichia coli (Takazawa et al., 1982). European Ganoderma species Ganoderma pfeifferi inhibited the growth of methicillin-resistant Staphylococcus aureus and other bacteria by new sesquiterpenoid hydroquinones (Mothana et al., 2000). Besides, this it was found that whole extracts of this mushroom inhibit the growth of microorganisms responsible for skin problems (Pityrosporum ovale, Staphylococcus epidermidis, Propionibacterium acnes).

Applanoxidic acid A (8) isolated from Ganoderma annulare, shows weak antifungal activity against Trichophyton mentagrophytes (Smania et al., 2003). Steroids like $5 \alpha$-ergosta- 7, 22-dien-3 $\beta$-ol or 5,8-epidioxy-5 $\alpha, 8 \alpha$-ergosta- 6,22 -dien-3 $\beta$-ol, isolated from Ganoderma applanatum, proved to be weakly active against a number of grampositive and gramnegative microorganisms (Smania et al., 1999). Oxalic acid is one agent responsible for the antimicrobial effect of Lentinula edodes (Berk.) against $S$. aureus and other bacteria (Bender et al., 2003). Ethanolic mycelial extracts from $L$. edodes possess antiprotozoal activity against Paramecium caudatum (Badalyan, 2004). Epicorazins used in some parts of Yemen for the treatment of 'nappy rash' of babies and in South Africa against sun burn belong to the group of epipolythiopiperazine-2,5-diones, an important class of biologically active fungal metabolites. Other antimicrobial compounds from the Aphyllophorales were summarized by (Zjawiony, 2004).

\section{Mushrooms as antiviral agents}

In contrast to bacterial infectious diseases, viral diseases cannot be treated by common antibiotics and specific drugs are urgently needed. Antiviral effects are described not only for whole extracts of mushrooms but also for isolated compounds. They may act directly by inhibition of viral enzymes, synthesis of viral nucleic acids or adsorption and uptake of viruses into mammalian cells. These direct antiviral effects are exhibited especially by smaller molecules. Indirect antiviral effects are the result of the immunostimulating activity of polysaccharides or other complex molecules (Brandt \& Piraino, 2000). Small molecular compounds with antiviral activities, several triterpenes from Ganoderma lucidum (i.e. ganoderiol F (2), ganodermanontriol (3), ganoderic acid $B(4)$ ) are active as antiviral agents against human immunodeficiency virus type 1 (HIV-1) (El-Mekkawy et al., 1998). Ganodermadiol (5), lucidadiol (6) and applanoxidic acid G (7), isolated from G. pfeifferi, but also from other known Ganoderma species, possess in vitro antiviral activity against influenza virus type A (IC50 values in MDCK cells $>0.22 ; 0.22$ and $0.19 \mathrm{mmol}$, respectively). Further, ganodermadiol is active against herpes simplex virus type 1, causing lip exanthema and other symptoms (IC50 in Vero cells $0.068 \mathrm{mmol}$ ) (Mothana et al., 2003). In vitro antiviral activity against influenza viruses type A and B was demonstrated for mycelial extracts of Kuehneromyces mutabilis (Mentel et al., 1994), and two isolated phenolic compounds from Inonotus hispidus (Awadh et al., 2003) and ergosterol peroxide, present in several mushrooms (Lindequist et al., 1989). The antiviral activity of Collybia maculata (vesicular stomatitis viruses in BHK cells) is due to purine derivatives (Leonhardt et al., 1987).

Mushrooms as antiallergic agents

Although extracts of many mushrooms can 
stimulate the immune system, while others suppress immune responses. This could be of interest, e.g. for the treatment of allergic diseases that are increasing worldwide. Ethanolic extracts of the edible Japanese basidiomycetes $H$. marmoreus, $F$. velutipes, Pholiota nameko and Pleurotus eryngii show significant antiallergic effects in mice (oxazolone-induced type IV allergy) also after p.o. application (Sano et al., 2002). Some compounds from G. lucidum (ganoderic acids $\mathrm{C}$ and $\mathrm{D}$ ); inhibit the histamine release from rat mast cells (Kohda et al., 1985; Tasaka et al., 1988). Eating of Tricholoma populinum J. E. Lange led to the regression of severe allergic symptoms in a patient with thromboangitis obliterans and in another patient with urticaria (Kreisel et al., 1990). Hispolon (10) and hispidin (11), isolated from fruit bodies of I. hispidus, inhibit the chemiluminescence response of human mononuclear blood cells and the mitogeninduced proliferation of spleen lymphocytes of mice (Ali et al., 1996).

\section{Mushrooms as anti-inflammatory agents}

Ethanolic extracts and a proteoglycan from $P$. linteus show anti-inflammatory effect in the collageninduced arthritis and in the croton oil-induced ear edema test in mice and antinociceptive effect in the writhing test (Kim et al., 2004; Kim et al., 2003). Other compounds effective in the writhing test are the ganoderic acids $\mathrm{A}$, $\mathrm{B}, \mathrm{G}$ and $\mathrm{H}$, isolated from G. lucidum. These substances showed a stronger effect in this animal model than acetylsalicylic acid (Koyama et al., 1997). Methanolic extract of Pleurotus pulmonarius fruiting bodies (500 and $1000 \mathrm{mg} / \mathrm{kg}$ ) reduced carrageenan-induced and formalin-induced paw edema in mice. The activity was comparable to the reference diclofenac $(10 \mathrm{mg} / \mathrm{kg})$. The IC50 value for hydroxyl-radical scavenging was 476 $\mathrm{mg} / \mathrm{mL}$ and for lipid peroxidation inhibition $960 \mathrm{mg} / \mathrm{ml}$ (Jose et al., 2002). The edible mushroom G. frondosa contains ergosterol (1), ergosta-4-6-8(14), 22-tetraen3-one and 1-oleoyl-2-linoleoyl-3-palmitoylglycerol, which inhibit cyclooxygenases I and II activity (Zhang et al., 2002).

\section{Mushrooms as hepatoprotective agents}

Ganoderic acids $R$ and $S$ and ganosporeric acid A from $G$. lucidum show in vitro antihepatotoxic activity in the galactosamine-induced cytotoxic test with primary cultured rat hepatocytes (Hirotani et al., 1986; Chen \& Yu, 1993). In vivo study of two fractions of total triterpenoids extract of G. lucidum (75\% ethanol) protected mice against hepatic necrosis induced by chloroform and D-galactosamine. The hepatoprotective effects were perhaps related to the ability to promote the activity of scavenging enzymes for hepatic free radicals in mice, and thus to raise the ability of antioxidation in mice (Wang et al., 2002).

Ganopoly, the polysaccharide-containing preparation of G. lucidum, was proven in a double-blind, randomized and multicentered study in patients with chronic hepatitis B (HBV DNA positive; application of Ganopoly for twelve weeks, then thirteen weeks followed up, $600 \mathrm{mg}$ three times per day equal to 27 $\mathrm{g}$ fruiting body, p.o.). Within the six months study period, $33 \%(17 / 52)$ of treated patients had normal aminotransferase values and 13\% (7/52) had cleared hepatitis B surface antigen from serum, whereas none of the controls had normal enzyme values (Gao et al., 2002).

Mushrooms as centrally acting agents

Apart from well investigated psychoactive mushrooms like Amanita muscaria or Psilocybe species some further mushroom extracts and compounds have been found with special central effects that could be of pharmacological interest. Phenol-analogous compounds (hericenons C, D, E, F, G, H) from $H$. erinaceus induce the synthesis of nerve growth factor and might have an ameliorative effect in Alzheimer's dementia (Mizuno, 1999). Erinacin E (9) from Hericium coralloides fermentation broth is a highly selective agonist at the kappa opiod receptor (IC50 of $0.8 \mathrm{mM}$, binding at the $\mathrm{m}$ opiod receptor with an I 50 of $>200 \mathrm{mM}$ ). Such compounds may exhibit antinociceptive activity without side effects observed with $\mathrm{m}$ receptor agonists like morphine (Saito et al., 1998). Screening investigations of selected basidiomycetes indicate inhibitory effects of $P$. betulinus, G. applanatum, H. annosum, Fomitopsis pinicola and Daedaleopsis confragosa on neutral endopeptidase (enkephalinase) (IC50 values between 40 and $55 \mathrm{mg} / \mathrm{mL}$ ). Selective inhibitors of this metalloendopeptidase could be useful in the treatment of pain with a spectrum of activity similar to that of opioids (Melzig et al., 1996). Scutigeral (15), isolated from fruiting bodies of Scutiger ovinus has affinity to the brain dopamine D1 receptors and may act as an orally active pain killer targeting vanilloid receptors (VR1) (Szallasi et al., 1999). Albaconol (16) from the fruiting bodies of Scutiger confluens is an antagonist at the VR1 receptor with an IC50 value of $5 \mathrm{mM}$ (Liu, 2002).

\section{Other activities}

Some triterpenes from G. lucidum (ganoderic acid $\mathrm{C}$ and derivatives) are able to inhibit the biosynthesis of cholesterol (Komoda et al., 1989) as well. Other triterpenes of this fungus contribute to atherosclerosis 
protection by inhibition of angiotensin converting enzyme (ganoderic acid F) (Morigiwa et al., 1986) or of platelet aggregation (ganoderic acid S) ( $\mathrm{Su}$ et al., 1999). The antioxidative and free radical scavenging effects of polysaccharides and triterpenoids from $G$. lucidum were shown in different oxidative injury models including tert-butylhydroperoxide damaged mice peritoneal macrophages, alloxan-induced diabetes and experimental liver injury models. The inhibition of low density lypoproteins (LDL) oxidation by endothelial cells and of monocyte adhesion to endothelial cells has been demonstrated (Lin, 2004). The antilipidemic effect of $L$. edodes is caused by eritadenin, a nucleotide derivative (Tokuda et al., 1974). Betulinan A (14) from Lenzites betulinus is about four times more active as a radical scavenger than vitamin $\mathrm{E}$ in inhibition of lipid peroxidation (Lee et al., 1996). Ergosta-4-6-8(14), 22tetraen-3-one, isolable from many mushrooms, has been shown to possess antialdosteronic diuretic properties (Yuan et al., 2004). Potentiators of ADP-induced platelet aggregation have been found in Polyporus umbellatus $(5 \alpha$, $8 \alpha$-epidioxy-ergosta-6, 22-dien-3-ol (4)) and others (Lu et al., 1985).

\section{Conclusion}

The mushrooms may be used directly in the diet to promote health, taking advantage of the additive and synergistic effects of the bioactive compounds present in them. The potential therapeutic implications of mushrooms are enormous but, detailed mechanisms of the various health benefits of mushrooms to humans still require intensive investigation, especially with the emergence of new evidence of their health benefit effects. The exploration of newly cultivated mushrooms and isolation of their active ingredients with mechanism based potential therapeutic value remains a challenge and hence mushrooms will keep on to be the foremost spotlight of research in the upcoming prospect as well.

\section{References}

Ahmad N, Bansal AK, Kidwai JR 1984. Effect of PHA-B fraction of Agaricus bisporus lectin on insulin release and $45 \mathrm{Ca} 2 \mathrm{C}$ uptake by islet of Langerhans in vitro. Acta Diabetol 21: 63-70.

Alarcon-Aguilara FJ, Roman-Ramos R, Perez-Gutierrez S, Aguilara-Contreras A, Contreras-Weber CC, FloresSanez JL 1998. Study of the antihyperglycemic effect of plants used as antidiabetics. J Ethnopharmacol 61: 101-110.

Ali NAA, Pilgrim H, Ludke J, Lindequist U 1996. Inhibition of chemiluminescence response of human mononuclear cells and suppression of mitogeninduced proliferation of spleen lymphocytes of mice by hispolon and hispidin. Pharmazie 51: 667-670.

Awadh AAN, Mothana RAA, Lesnau A, Pilgrim H, Lindequist U 2003. Antiviral activity of extracts and compounds from Inonotus hispidus. Fitoterapia 74: 483-485.

Badalyan SM 2004. Antiprotozoal activity and mitogenic effect of mycelium of culinary-medicinal shiitake mushroom Lentinus edodes (Berk.) Singer (Agaricomycetidae). Int J Med Mushrooms 6: 131-138.

Bano Z, Rajarathnam S 1988. Pleurotus mushrooms. Part II. Chemical composition, nutritional value, post-harvest physiology, preservation, and role as human food. Crit Rev Food Sci Nutr 27: 87-158.

Barros L, Cruz T, Baptista P, Estevinho LM, Ferreira IC 2008. Wild and commercial mushrooms as source of nutrients and nutraceuticals. Food Chem Toxicol 46: 2742-2747.

Beattie G, Lannom R, Lipsick J, Kaplan NO, Osler AG 1980. Streptozotocin-induced diabetes in athymic and conventional BALB/c mice. Diabetes 29: 146-150.

Benedict RG, Brady LR 1972. Antimicrobial activity of mushroom metabolites. J Pharmacol Sci 61: 18201822 .

Bender S, Dumitrache CN, Backhaus J, Christie G, Cross RF, Lonergan GT 2003. A case for caution in assessing the antibiotic activity of extracts of culinary-medicinal Shiitake mushroom [Lentinus edodes (Berk.)Singer] (Agaricomycetidae). Int J Med Mushrooms 5: 31-35.

Bobek P, Ginter E, Jurcovicova M, Kuniak L 1991. Cholesterollowering effect of the mushroom Pleurotus ostreatus in hereditary hypercholesterolemic rats. Ann Nutr Metab 35: 191-195.

Bobek P, Ozdin L, Kuniak L 1993. Influence of water and ethanol extracts of the oyster mushroom (Pleurotus ostreatus) on serum and liver lipids of the Syrian hamsters. Nahrung 37: 571-575.

Bobek P, Ondreicka R, Klvanova J, Ozdin L 1994. Oyster mushroom (Pleurotus ostreatus) decreases serum and liver cholesterol and increase cholesterol $7 \beta$ hydroxylase activity and fecal excretion of neutral sterols and bile acids in hypercholesterolemic rats. Nutr Res 14: 1689-1699.

Bobek P, Hromadova M, Ozdin L 1995. Oyster mushroom (Pleurotus ostreatus) reduces the activity of 3-hydroxy-3-methylglutaryl $\mathrm{CoA}$ reductase in rat liver microsomes. Experientia 51: 589-591.

Bobek P, Ozdin L, Galbavy S 1998. Dose- and time-dependent hypocholesterolemic effect of oyster mushroom (Pleurotus ostreatus) in rats. Nutrition 14: 282-2826.

Brandt CR, Piraino F 2000. Mushroom antivirals. Recent Res Dev Antimicrob Agents Chemother 4: 11-26.

Burczyk J, Gawron A, Slotwinska M, Smietana B, Terminska K 1996. Antimitotic activity of aqueous extracts of Inonotus obliquus. Boll Chim Farm 135: 306-309.

Chang ST, Miles PG 1992. Mushrooms biology - a new discipline. Mycologist 6: 64-65. 
Chang ST, Buswell JA, Chiu SW 1993. Mushroom Biology and Mushroom Products. Hong Kong: The Chinese University Press.

Chang ST, Miles PG 2004. The nutritional attributes of edible mushrooms. In Mushrooms: Cultivation, Nutritional Value, Medicinal Effect, and Environmental Impact. Boca Raton, FL: CRC Press, p. 27-38.

Chen Q 1989. Antilipemic effect of polysaccharides from Auricularia auricular, Tremella fuciformis, and Tremella fuciformis spores. Zhongguo Yaoke Daxue Xuebao 20: 344-347.

Chen RY, Yu DQ 1993. Studies on the triterpenoid constituents of the spores from Ganoderma lucidum Karst. J Chin Pharm Sci 2: 91-96.

Chihara G, Maeda Y, Sasaki T, Fukuoka F 1969. Inhibition of mouse sarcoma 180 by polysaccharides from Lentinus edodes (Berk.). Nature 222: 687-688.

Cheung PCK 1996. The hypocholesterolemic effect of two edible mushrooms: Auricularia auricula (treeear) and Tremella fuciformis (white jelly-leaf) in hypercholesterolemic rats. Nutr Res 16: 1721-1725.

Cheung PCK 1996. The hypocholesterolemic effect of extracellular polysaccharide from the submerged fermentation of mushroom. Nutr Res 16: 1953-1957.

Cheung PCK 1997. Chemical evaluation of some lesserknown edible mushroom mycelia produced in submerged culture from soymilk waste. Food Chem 60: 61-65.

Cheung LM 2001. Evaluation of the antioxidant activity and characterization of extracts from three edible Chinese mushrooms. M. Phil. thesis. Hong Kong: Chinese University of Hong Kong.

Cheung LM, Cheung PCK, Ooi VEC 2003. Antioxidant activity and total phenolics of edible mushroom extracts. Food Chem 81: 249-255.

Cimerman NG 1999. Medicinal value of the genus Pleurotus (Fr.) P. Karst. (Agaricales S. R., basidiomycetes). Int J Med Mushrooms 1: 69-80.

Clifford AJ, Heid MK, Peerson JM, Bills ND 1991. Bioavailability of food folates and evaluation of food matrix effects with a rat bioassay. J Nutr 121: 445453.

Diez VA, Alvarez A 2001. Compositional and nutritional studies on two wild edible mushrooms from northwest Spain. Food Chem 75: 417-422.

Elmastas M, Isildak O, Turkekul I, Temur N 2007. Determination of antioxidant activity and antioxidant compounds in wild edible mushrooms. J Food Compos Anal 20: 337-345.

El-Mekkawy S, Meselhy MR, Nakamura N, Tezuka Y, Hattori M, Kakiuchi N 1998. Anti-HIV-1 and antiHIV-1-protease substances from Ganoderma lucidum. Phytochemistry 49: 1651-1657.

Eo SK, Kim YS, Lee CK, Han SS 1999. Antiviral activities of various water and methanol soluble substances isolated from Ganoderma lucidum. J Ethnopharmacol 68: 129-136.

Ewart RBL, Kornfield S, Kipnis DM 1975. Effect of lectins on hormone release from isolated rat islets of Langerhans. Diabetes 24: 705-714.

Fujimoto S, Furue H, Kimura T, Kondo T, Orita K, Taguchi $T$ 1991. Clinical outcome of postoperative adjuvant immunochemotherapy with sizofiran for patients with resectable gastric cancer-a randomized controlled study. Eur J Cancer 27: 1114-1118.

Fukushima M, Nakano M, Morii Y, Ohashi T, Fujiwara Y, Sonoyama K 2000. Hepatic LDL receptor mRNA is increased by dietary mushroom (Agaricus bisporus) fiber and sugar beet fiber. J Nutr 130: 2151-2156.

Fukushima M, Ohashi T, Fujiwara Y, Sonoyama K, Nakano M 2001. Cholesterol-lowering effects of Maitake (Grifola frondosa) fiber, Shiitake (Lentinus edodes) fiber, and Enokitake (Flammulina velutipes) fiber in rats. Exp Biol Med 226: 758-675.

Gao Y, Zhou S, Chen G, Dai X, Ye J, Gao H 2002. A phase I/ II study of a Ganoderma lucidum (Curt.:Fr.) P.Karst. (Ling Zhi, Reishi mushroom) extract in patients with chronic hepatitis B. Int J Med Mushrooms 4: 23212327.

Gao Y, Lan J, Dai X, Ye J, Zhou S 2004. A phase I/II study of ling zhi mushroom Ganoderma lucidum (W.Curt.:Fr.) Lloyd (Aphyllophoromycetidae) extract in patients with type II diabetes mellitus. Int J Med Mushrooms 6: 33-39.

Gordon M, Guralnik M, Kaneko Y, Mimura T, Goodgame J, DeMarzo C 1995. A phase II controlled study of a combination of the immune modulator, lentinan, with didanosine (DDI) in HIV patients with CD4 cells of 200-500/MM (3). J Med 26: 193-207.

Gray AM, Flatt PR 1998. Insulin-releasing and insulinlike activity of Agaricus campestris (mushroom). $J$ Endocrinol 157: 259-266.

Hasler CM 1996. Functional food: the Western perspective. Nut Rev 54: 506-510.

Hazama S, Oka M, Yoshino S, Iizuka N, Wadamori Kyamamoto 1995. Clinical effects and immunological analysis of intraabdominal and intrapleural injection of lentinan for malignant ascites and pleural effusion of gastric carcinoma. Cancer Chemoth Pharm 22: 1595-1597.

Hikino H, Konno C, Mirin Y, Hayashi T 1985. Isolation and hypoglycaemic activities of ganoderans $\mathrm{A}$ and $\mathrm{B}$, glucans of Ganoderma lucidum fruit bodies. Planta Med 51: 339-340.

Hirotani M, Ino C, Furuya T, Shiro M 1986. Ganoderic acids $\mathrm{T}, \mathrm{S}$ and $\mathrm{R}$, new triterpenoids from the cultured mycelia of Ganoderma lucidum. Chem Pharm Bull 34: 2282-2285.

Horio H, Ohtsuru M 2001. Maitake (Grifola frondosa) improve glucose tolerance of experimental diabetic rats. J Nutr Sci Vitaminol 47: 57-63. 
Hsu TH, Lo HC 2002. Biological activity of Cordyceps (Fr.) Link species (ascomycetes) derived from a natural source and from fermented mycelia on diabetes in STZ-induced rats. Int J Med Mushrooms 4: 111-125.

Ishikawa Y, Marimoto K, Hamasaki T 1984. Flavoglaucin, a metabolite of Eurotium chavalieri, its oxidation and synergism with tocopherol. J Am Oil Chem Soc 61: 1864-1868.

Jose N, Ajith TA, Jananrdhanan KK 2002. Antioxidant, antiinflammatory and antitumor activities of culinarymedicinal mushroom Pleurotus pulmonarius (Fr.) Quel. (Agaricomycetidae). Int J Med Mushrooms 4: 329-335.

Kabir Y, Kimura S 1989. Dietary mushrooms reduce blood pressure in spontaneously hypertensive rats. $J$ Nutr Sci Vitaminol 35: 91-94.

Kahlos K, Kangas L, Hiltunen R 1987. Antitumor activity of some compounds and fractions from an n-hexane extract of Inonotus obliquus in vitro. Acta Pharm Fennica 96: 33-40.

Kaneda T, Tokuda S 1966. Effect of various mushroom preparations on cholesterol levels in rats. J Nutr 90: 371-376.

Karinaga R, Mizu M, Koumoto K, Anada T, Shinkai S, Kimura $\mathrm{T}$ 2004. First observation by fluorescence polarization of complexation between mRNA and the natural polysaccharide schizophyllan. Chem Biodivers 1: 634639.

Kasuga A, Aoyagi Y, Sugahara T 1993. Antioxidative activities of several mushroom extracts. J Japanese Soc Food Sci Technol 40: 56-63.

Kiho T, Sobue S, Ukai S 1994. Structural features and hypoglycemic activities of two polysaccharides from a hot-water extract of Agrocybe cylindracea. Carbohyd Res 251: 81-87.

Kiho T, Tsujimura Y, Sakushima M, Usui S, Ukai S 1994. Polysaccharide in fungi. XXXIII. Hypoglycemic activity of an acidic polysaccharide (AC) from Tremella fuciformis. Yakuga Zasshi 114: 308-315.

Kiho T, Morimoto H, Sakushima M, Usui S, Ukai S 1995. Polysaccharides in fungi. XXXV. Antidiabetic activity of an acidic polysaccharide from the fruiting bodies of Tremella aurantia. Biol Pharm Bull 18: 1627-1629.

Kiho T, Morimoto H, Kobayashi T, Usui S, Ukai S, Aizawa K 2000. Effect of a polysaccharide (TAP) from the fruiting bodies of Tremella aurantia on glucose metabolism in mouse liver. Biosci Biotech Bioch 64: 417-419.

Kiho T, Kochi M, Usui S, Hirano K, Aizawa K, Inakuma T 2002. Antidiabetic effect of an acidic polysaccharide (TAP) from Tremella aurantia Schw.:Fr. (Heterobasidiomycetes) in genetically diabetic KKAy mice. Int J Med Mushrooms 4: 291-297.

Kim MY, Park MH, Kim GH 1997. Effects of mushroom protein-bound polysaccharides on the blood glucose levels and energy metabolism in streptozotocin induced diabetic rats. J Korean Nutr 30: 743-750.

Kim DH, Yang BK, Jeong SC, Hur NJ, Das S, Yun JW 2001. A preliminary study on the hypoglycemic effect of the exo-polymers produced by five different medicinal mushrooms. J Microbiol Biotechn 11: 167-171.

Kim GY, Kim SH, Hwang SY, Kim HY, Park YM, Park SK 2003. Oral administration of proteoglycan isolated from Phellinus linteus in the prevention and treatment of collagen-induced arthritis in mice. Biol Pharm Bull 26: 823-831.

Kim SH, Song YS, Kim SK, Kim BC, Lim CJ, Park EH 2004. Anti-inflammatory and related pharmacological activities of the $\mathrm{n}-\mathrm{BuOH}$ subfraction of mushroom Phellinus linteus. J Ethnopharmacol 93:141-146.

Kodama N, Komuta K, Nanba H 2002. Can maitake MDfraction aid cancer patients? Altern Med Rev 7: 236239.

Kohda H, Tokumoto W, Sakamoto K, Fujii M, Hirai Y, Yamasaki K 1985. The biologically-active constituents of Ganoderma lucidum (Fr) Karst-histamine releaseinhibitory triterpenes. Chem Pharm Bull 33: 13671373.

Komoda Y, Shimizu M, Sonoda Y, Sato Y 1989. Ganoderic acid and its derivatives as cholesterol synthesis inhibitors. Chem Pharm Bull 37: 531-533.

Konno S, Aynehchi S, Dolin DJ, Schwartz AM, Choudhury MS, Tazakin HN 2002. Anticancer and hypoglycemic effects of polysaccharides in edible and medicinal Maitake mushroom [Grifola frondosa (Dicks.:Fr.) S.F.Gray]. Int J Med Mushrooms 4: 185-195.

Koyama K, Imaizumi T, Akiba M, Kinoshita K, Takahashi L, Suzuki A 1997. Antinociceptive components of Ganoderma lucidum. Planta Med 63: 224-227.

Kreisel H, Lindequist U, Horak M 1990. Distribution, ecology and immunosuppressive properties of Tricholoma populinum (Basidiomycetes). Zentralbl Mikrobiol 145: 393-396.

Kubo K, Aoki H, Nanba H 1994. Antidiabetic activity present in the fruit body of Grifola frondosa (Maitake). I. Biol Pharm Bull 17: 1106-1110.

Kubo K, Nanba H 1997. Anti-hyperliposis effect of Maitake fruit body (Grifola frondosa). I. Biol Pharm Bull 20: 781-785.

Kupra J, Anke T, Oberwinkler G, Schramn G, Steglich W 1979. Antibiotics from basidiomycetes VII. Crinipellis stipitaria (Fr.) Pat. J Antibiot 32: 130-135.

Kurushima H, Kodama N, Nanba H 2000. Activities of polysaccharides obtained from Grifola frondosa on insulin-dependent diabetes mellitus induced by streptozotocin in mice. Mycosci 41: 473-480.

Lee IK, Yun BS, Cho SM, Kim WG, Kim JP, Ryoo IJ 1996. Betulinans A and B, two Benzoquinone Compounds from Lenzites betulina. J Nat Prod 59: 1090-1092.

Lee YL, Yen MT, Mau JL 2007. Antioxidant properties of 
various extracts from Hypsizigus marmoreus. Food Chem 104: 1-9.

Leonhardt K, Anke T, Hillen-Maske E, Steglich W 1987. 6-Methylpurine, 6-methyl-9- $\beta$-D-ribofuranosylpurine, and 6-hydroxymethyl-9- $\beta$-D-ribofuranosylpurin as antiviral metabolites of Collybia maculata (basidiomycetes). Z Naturforsch C 42: 420-424.

Lin ZB 2004. Focus on anti-oxidative and free radical scavening activity of Ganoderma lucidum. J Appl Pharmacol 12: 133-137.

Lindequist U, Lesnau A, Teuscher E, Pilgrim H 1989. Untersuchungen zur antiviralen Wirksamkeit von Ergosterolperoxid. Pharmazie 44: 579-580.

Lindequist U, Teuscher E, Narbe G 1990. Neue Wirkstoffe aus Basidiomyceten. Phytother 11: 139-149.

Liu J 2002. Biologically active substances from mushrooms in Yunnan, China. Heterocycles 57: 157-167.

Lo KM, Cheung PCK 2005. Antioxidant activity of extracts from the fruiting bodies of Agrocybe aegerita var. alba. Food Chem 89: 533-539.

Longvah T, Deosthale YG 1998. Composition and nutritional studies on edible wild mushroom from northeast India. Food Chem 63: 331-334.

Lu W, Adachi I, Kano K, Yasuta A, Toriizuka K, Ueno M 1985. Platelet aggregation potentiators from Cho-Re. Chem Pharm Bull 33: 5083-5087.

Lucas EH, Montesano R, Pepper MS, Hafner M, Sablon E 1957. Tumor inhibitors in Boletus edulis and other holobasidiomycetes. Antibiot Chemother 7: 1-4.

Lucas EH, Byerrum M, Clarke DA, Reilly HC, Stevens JA, Stock CC 1958. Production of oncostatic principles in vivo and in vitro by species of the genus Calvatia. Antibiot Annu 6: 493- 496.

Maga JA 1981. Mushroom flavor. J Agr Food Chem 29: 1-4.

Manzi P, Gambelli L, Marconi S, Vivanti V, Pizzoferrato L 1999. Nutrients in edible mushrooms: An inter-species comparative study. Food Chem 65: 477-482.

Manzi P, Aguzzi A, Pizzoferrato L 2001. Nutritional value of mushrooms widely consumed in Italy. Food Chem 73: 321-325.

Mattila P, Konko K, Euvola M, Pihlava J, Astola J, Vahteristo L 2001. Contents of vitamins, mineral elements and some phenolic compound in cultivated mushrooms. $J$ Agr Food Chem 42: 2449-2453.

Mau JL, Chao GR, Wu KT 2001. Antioxidant properties of methanolic extracts from several ear mushrooms. $J$ Agr Food Chem 49: 5461-5467.

Mau JL, Lin HC, Chen CC 2001. Non-volatile taste components of several medicinal mushrooms. Food Res Int 34: 521-526.

Mau JL, Lin HC, Ma JT, Song SF 2001. Non-volatile taste components of several specialty mushrooms. Food Chem 73: 461-466.

Mau JL, Lin HC, Song SF 2002. Antioxidant properties of several specialty mushrooms. Food Res Int 35: 519-
526.

Melzig MF, Pieper S, Siems WE, Heder G, Bottger A, Liberra K 1996. Screening of selected basidiomycetes for inhibitory activity on neutral endopeptidase (NEP) and angiotensin-converting enzyme (ACE). Pharmazie 51: 501-503.

Mentel R, Meinsen D, Pilgrim H, Herrmann B, Lindequist $\mathrm{U}$ 1994. In vitro antiviral effect of extracts of Kuehneromyces mutabilis on influenza virus. Pharmazie 49: 859-860.

Miles PG, Chang ST 1997. Mushroom Biology-Concise Basics and Current Developments. Singapore: World Scientific, 144.

Mizuno T 1995. Bioactive biomolecules of mushrooms: Food function and medicinal effect of mushroom fungi. Food Rev Int 11: 7-12.

Mizuno T 1999. The extraction and development of antitumoractive polysaccharides from medicinal mushrooms in Japan (review). Int J Med Mushrooms 1: 9-30.

Mizuno T 1999. Bioactive substances in Hericium erinaceus (Bull.:Fr.) Pers. (Yamabushitake), and its medicinal utilization. Int J Med Mushrooms 1: 105-119.

Molitoris HP 1994. Mushrooms in medicine. Folia Microbiol 39: 91-98

Morigiwa A, Kitabatake K, Fujimoto Y, Ihekawa N 1986. Angiotensin converting enzyme inhibitory triterpenes from Ganoderma lucidum. Chem Pharm Bull 34: 3025-3028.

Mothana RAA, Jansen R, Julich WD, Lindequist U 2000. Ganomycin A and B, new antimicrobial farnesyl hydroquinones from the basidiomycete Ganoderma pfeifferi. J Nat Prod 63: 416-418.

Mothana RAA, Awadh NAA, Jansen R, Wegner U, Mentel R, Lindequist U 2003. Antiviral lanostanoid triterpenes from the fungus Ganoderma pfeifferi Bres. Fitoterapia 74: 177-180.

$\mathrm{Ng}$ YF 2005. In vitro and in vivo antioxidant activity and hypocholesterolemic effect in extracts of Agrocybe aegerita. M.Phil. thesis. Hong Kong: The Chinese University of Hong Kong.

Ochiai T, Isono K, Suzuki T, Koide Y, Gunji Y, Nagata M 1992. Int J Immunother 8: 161-169.

Reshetnikov SV, Wasser SP, Tan KK 2001. Higher basidiomycetes as a source of antitumor and immunostimulating polysaccharides (review). Int $J$ Med Mushrooms 3: 361-394.

Ribeiroa B, Pinhoa PG, Andradea PB, Baptistab P, Valentao P 2009. Fatty acid composition of wild edible mushrooms species: A comparative study. Microchem J 93: 29-35.

Ryong LH, Tertov VV, Vasiley AW, Tutelyan VA, Orekhov AN 1989. Antiatherogenic and antiatherosclerotic effects of mushroom extracts revealed in human aortic intima cell culture. Drug Develop Res 17: 109-117.

Sadler M, Saltmarsh M 1998. Funtional Foods: The Consumer, 
the Products and the Evidence, Royal Society of Chemistry, Cambridge.

Saito T, Aoki F, Hirai H, Inagaki T, Matsunaga Y, Sakakibara $\mathrm{T}$ 1998. Erinacine E as a kappa opioid receptor agonist and its new analogs from a basidiomycete, Hericium ramosum. J Antibiot 51: 983-990.

Sano M, Yoshino K, Matsuzawa T, Ikekawa T 2002. Inhibitory effects of edible higher basidiomycetes mushroom extracts on mouse type IV allergy. Int $J$ Med Mushrooms 4: 37-41.

Sato M, Tai T, Nunoura Y, Yajima Y, Kawashima S, Tanaka K 2002. Dehydrotrametenolic acid induces preadipocyte differentiation and sensitizes animal models of noninsulin-dependent diabetes mellitus to insulin. Biol Pharm Bull 25: 81-86.

Sheng J, Chen Q 1990. Effects of polysaccharides from Auricularia auricula, Tremella fuciformis, and Tremella fuciformis spores on experimental thrombin formation. Zhongguo Yaoke Daxue Xuebae 21: 3942.

Shimada Y, Yamakawa A, Morita T, Sugiyama K 2003. Effects of dietary eritadenine on the liver microsomal 1, 6-desaturase activity and its mRNA in rats. Biosci Biotech Bioch 67: 1258-1266.

Smania Jr A, Delle Monache F, Smania EFA, Cuneo RS 1999. Antibacterial activity of steroidal compounds isolated from Ganoderma applanatum (Pers.) Pat. (Aphyllophoromycetideae) fruit body. Int $\mathrm{J}$ Med Mushrooms 1: 325-330.

Smania EFA, Delle Monache F, Smania Jr A, Yunes RA 2003. Antifungal activity of sterols and triterpenes isolated from Ganoderma annulare. Fitoterapia 74: 375-377.

Su CY, Shiao MS, Wang CT 1999. Predominant inhibition of ganodermic acid $\mathrm{S}$ on the thromboxane A2-dependent pathway in human platelets response to collagen. Biochim Biophys Acta 1437: 223-234.

Sugahara T, Arai S, Aoyagi Y, Kunisaki N 1975. Contents of 50-nucleotides and free amino acids in different varieties of dried shiitake mushroom (Lentinus edodes Sing.). J Jpn Soc Food Sci 28: 477-483.

Sugiyama K, Akachi T, Yamakawa A 1995. Hypocholesterolemic action of eritadenine is mediated by a modification of hepatic phospholipid metabolism in rats. J Nutr 125 : 2134-2144.

Sun MT, Xiao JT, Zhang SQ, Liu YJ, Li ST 1984. Therapeutic effect of some foods on hyperlipidermia in man. Acta Nutr Sinica 6: 127-133.

Suzuki S, Ohshima S 1976. Influence of shiitake (Lentinus edodes) on human serum cholesterol. Mushroom Sci 9: 463-470.

Swanston-Flatt SK, Day C, Flatt PR, Gould BJ, Bailey CJ 1989. Glycemic effects of traditional European plant treatments for diabetes: Studies in normal and streptozotocin diabetic mice. Diabetes Res 10: 69-73.

Szallasi A, Biro T, Szabo T, Modarres S, Petersen M, Klusch
A 1999. A non-pungent triprenyl phenol of fungal origin, scutigeral, stimulates rat dorsal root ganglion neurons via interaction at vanilloid receptors. Britt $J$ Pharmacol 126: 1351-1358.

Taguchi T, Furue H, Kimura T, Kondoh T, Hattori T, Itoh I 1982. Life-span prolongation effect of lentinan on patients with advanced or recurrent colorectal cancer. Int J Immunopharmaco 4: 271.

Takazawa H, Tajima F, Miyashita C 1982. An antifungal compound from "Shiitake" (Lentinus edodes). Yakuga Zasshi 102: 489-491.

Tasaka K, Mio M, Izushi K, Akagi M, Makino T 1988. Anti-allergic constituents in the culture medium of Ganoderma lucidum. (II). The inhibitory effect of cyclooctasulfur on histamine release. Agents Actions 23: 157-160.

Thekkuttuparambil AA, Kainoor K 2007. Janardhanan. Indian Medicinal Mushrooms as a Source of Antioxidant and Antitumor Agents. J Clin Biochem Nutr 40: 157-162.

Tokita F, Shibukawa N, Yasumoto T, Kaneda T 1972. Isolation and chemical structure of the plasma-cholesterol reducing substance from Shiitake mushroom. Mushroom Sci 8: 783-788.

Tokuda S, Tapiri A, Kano E, Sugwara Y, Suzuki S, Sato H 1974. Reducing mechanism of plasma cholesterol by Shiitake. Mushroom Sci 9: 445-461.

Tsai SY, Huang SJ, Mau JL 2006. Antioxidant properties of hot-water extracts from Agrocybe cylindracea. Food Chem 98: 670-677.

Wang HX, Liu WK, Ng TB, Ooi VEC, Chang ST 1995. Immunomodulatory and antitumor activities of polysaccharide-peptide complex from a mycelial culture of Tricholoma lobayense, a local edible mushroom. Life Sci 57: 269-281.

Wang HX, Liu WK, Ng TB, Ooi VEC, Chang ST 1996. The immunomodulatory and antitumor activities of lectins from the mushroom Tricholoma mongolicum. Immunopharmacology 31: 205-211.

Wang MY, Liu Q, Che QM, Lin ZB 2002. Effects of total triterpenoids extract from Ganoderma lucidum (Curt.:Fr.) P.Karst. (Reishi Mushroom) on experimental liver injury models induced by carbon tetrachloride or d-galactosamine in mice. Int $\mathrm{J} \mathrm{Med}$ Mushrooms 4: 337-342.

Wasser SP, Weis AL 1999. Medicinal properties of substances occurring in higher Basidiomycetes mushrooms: current perspectives (review). Int J Med Mushrooms 1: 31-62.

Wasser SP 2002. Medicinal mushrooms as a source of antitumor and immunomodulating polysaccharides. Appl Microbiol Biot 60: 258-274.

Windholz M 1983. The Merck Index, $10^{\text {th }}$ ed. Rahway, NJ: Merck and Co.

Yang JH, Lin HC, Mau JL 2002. Antioxidant properties of several commercial mushrooms. Food Chem 77: 229- 
235.

Yeung M, Cheung PCK 2002. The hypolipidemic effect of some lesser-known edible and medicinal mushrooms. Abstracts of the Institute of Food Technologists' Annual Meeting. Anaheim: Institute of Food Technologists.

Yip KP, Fung KP, Chang ST, Tam SC 1987. Purification and mechanism of the hypotensive action of an extract from edible mushroom Pleurotus sajor-caju. Neurosci Lett Suppl 28: S59.

Yuan D, Mori J, Komatsu K, Makino T, Kano Y 2004. An antialdosteronic diuretic component (drain dampness) in Polyporus sclerotium. Biol Pharm Bull 27: 867-870.

Zaidman BZ, Yassin M, Mahajna J, Wasser SP 2005. Medicinal mushroom modulators of molecular targets as cancer therapeutics. Appl Microbiol Biot 67: 453-468.

Zhang Y, Mills G, Nair MG 2002. Cyclooxygenase inhibitory and antioxidant compounds from the mycelia of the edible mushroom Grifola frondosa. J Agr Food Chem
50: 7581-7585.

Zhanga M, Cuia SW, Cheungb PCK, Wanga Q 2007. Antitumor polysaccharides from mushrooms: a review on their isolation process, structural characteristics and antitumor activity. Trends Food Sci Tech 18: 4-19.

Zhou S, Gao Y 2002. The immunomodulating effects of Ganoderma lucidum (Curt.:Fr.) P.Karst (LingZhi, Reishi Mushroom) (Aphylloromycetidae). Int J Med Mushrooms 4: 1-11.

Zjawiony J 2004. Biologically active compounds from Aphyllophorales (Polypore) fungi. J Nat Prod 67: 300-310.

\section{*Correspondence}

Permender Rathee

PDM College of Pharmacy, Bahadurgarh

pdmcop@rediffmail.com

Tel. +919466593965 